\title{
Why fertility has been declining in Finland after the Global Recession? A theoretical approach
}

\author{
HEIKKI HIILAMO, University of Helsinki
}

\begin{abstract}
A steady improvement in the economy and employment since 2010 did not stop the drop in total fertility rate in Finland. Declining fertility now includes women in almost all age and educational groups in the country. This decline has continued long enough to also indicate a dramatic decrease in completed fertility, which is a departure from decades of sustained levels of completed fertility. Drawing from a range of publicly available descriptive data, this article assesses the extent to which old and new theories of fertility are relevant in explaining this development. In conclusion, the fertility development in Finland is surprising, and challenges traditional theories on fertility, which analyse fertility from economic and gender perspectives. Social interaction theory holds more promise. However, it is very difficult to find data sources which could elucidate the role of social interaction in the fertility decline. Designing pro-natalistic policies is challenging before there is more detailed evidence and understanding concerning the key drivers of the fertility decline in Finland.
\end{abstract}

\section{Introduction}

Finland makes an interesting case with regard to fertility for two puzzling reasons. Firstly, fertility is declining in a country known for its high degree of gender equality and extensive policies to support reconciliation between work and family life, both of which have been theorized to support fertility. Secondly, the decline in fertility has continued in Finland, against expectations, even after the country's economy started to pick up and unemployment began decreasing in 2016.

Declining fertility has been a debated topic in Finnish policy circles. This is unsurprising given that fertility has major implications to welfare state sustainability, from the early childhood education system to pension system finance. This debate regarding fertility has been fuelled by media reports on the steady decline in the number of children born each month and year. The number of children born has dropped below the previous all-time lowest fertility experienced during the Famine of 1866-1868, when around $8.5 \%$ of the entire population died of hunger. 
The present paper is motivated by the need to understand the puzzling fertility predicament in Finland after the Global Recession which started in 2008. Drawing from a range of publicly available descriptive data, the paper investigates the extent to which different fertility theories offer relevant explanations to this trend. The main contribution for subsequent research is to direct research towards the most promising theoretical and empirical areas. We also try to identify potential data sources and methods for more thorough future analyses. This is an exploratory exercise where we do not draw detailed hypotheses to be tested with empirical data. Instead, we discuss the relevance and validity of the theories on a general level and point out potential avenues for more detailed hypothesis testing.

This paper starts by presenting recent trends in Finnish fertility and then introduces the methodological approach. Second, we discuss four commonly used theories micro-economic theory, gender equality theory, gender equity theory and social interaction theory - to explain fertility, and contrast the theories against the total fertility rate changes in Finland between 2008 and 2018. Finally, we map alternative theories which could be used to elucidate the pattern in Finland. We also discuss possible methods and data sources which could be used to explore the theories further.

\section{Finnish fertility trend after the Global Recession in 2008}

Changes in fertility are usually measured with the total fertility rate (TFR), which refers to the expected number of children born or likely to be born to a woman in her lifetime if she were subject to the prevailing rate of age-specific fertility in the population. Finland had a TFR of 1.87 in 2010, two years after the beginning of the Global Recession in 2008. Since 2010, the TFR has been steadily declining. In 2018, the TFR was 1.41 (Statistic Finland 2019a), which means that the TFR declined by 0.46 births per women between 2010 and 2018. This is a remarkable decline from a comparative perspective. The TFR in 2019, 1.35, is the all-time lowest TFR recorded in the Nordic countries (1.38 in Denmark in 1983).

The TFR measure is well-suited to study changes in the level and direction of fertility between countries or within countries. However, TFR estimates are distorted by changes in the timing of childbearing (tempo effects). They are depressed during years in which women delay childbearing and inflated in years when childbearing is accelerated (Bongaard and Feeney 1998). Completed fertility measures the actual number of children born to women during their fertile age.

As we are interested in a trend concerning a fairly short period, it is necessary to study if the decline in the TFR is only reflecting tempo effects or postponement, where women of fertile age postpone childbearing. Moreover, the timing of childbearing in low parities is sensitive to changes in socio-economic conditions. A study by Hellstrand et al. (2019) demonstrated that the tempo-adjusted fertility rate was decreasing in Finland in tandem with the observed TFR in 2010-2017. A common feature of childbearing 
behaviour in Finland has been a strong recuperation of postponed births at older ages, causing cohort fertility to remain stable although the age at entry into motherhood has increased. The new evidence suggests that after the Global Recession women of higher childbearing ages did not catch up on births to the same extent as previous generations did (Comolli 2018; Hellstrand et al. 2019).

Compared with Denmark, Norway and Sweden Finland had higher levels of fertility in the early 1990s and then lower levels towards the end of the 1990s and early 2000s, when the TFR started to converge (Nordic statistics 2019). Since 2019, the fertility trend in Finland is most similar to Norway, where a TFR of 1.56 in 2018 was also the lowest ever recorded in the country. In Norway, the continuous fertility decline started already in 2009, when the TFR was 1.98 (Figure 1).

Figure 1. TFR in four Nordic countries 2008-2018.

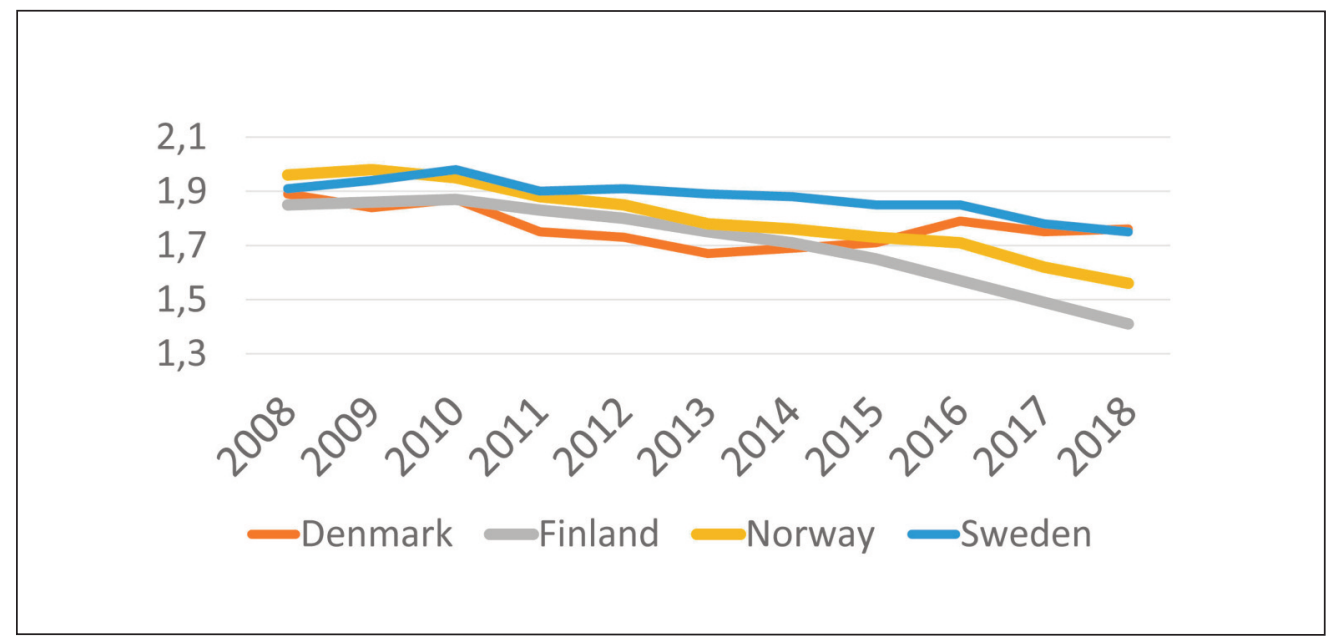

Source: Nordic statistics 2019.

Regarding long-term economic and social sustainability of the welfare state, the problem of lowest low fertility is larger in Finland than in Norway, which has constant revenues and substantial public assets in oil reserves. Changes in the economy do not seem to explain the continuous fall of fertility in Norway since 2009 either. These developments point to a more fundamental change in fertility patterns, which calls for alternative theories. Comparing the pattern in Finland with Norway does not provide easy answers either. Norway has the lowest levels of childlessness across all cohorts of women and men among the Nordic countries, while Finland has the highest levels (Jalovaara et al. 2019). 
There seems to be no consensus on the key drivers of declining fertility, which causes concerns when it comes to effective policy tools to increase fertility. The given explanations revolve around an increase in the age of first-time motherhood, changes in the culture concerning family formation and increases in childless lifestyles and social exclusion, particularly the increase in the share of low-educated jobless young men (Mäki 2019; Rotkirch et al. 2017).

\section{To what extent different theories explain the post- recession trend in fertility: Methodological approach}

The methodological approach of this paper is two-fold; first the key theories are described and then their relevance to the Finnish contexts is assessed while using a range of descriptive statistics from public data sources. The paper follows the path outlined by Huinink et al. (2015) by considering the sources of complexity in the number and diversity of factors and mechanisms relating to fertility changes in a single country context. By reviewing a number of theories presented in Leridon's (2015) overview, we chose on the basis of previous literature (Hellstrand et al. 2019; Mäki 2019; Jalovaara et al. 2019) three older theories (micro-economic theory, gender equality theory and gender equity theory) and one newer theory (social interaction theory), which were considered as the most promising candidates to explain the fertility pattern in Finland between 2008 and 2019. These four commonly used theoretical approaches explain fertility in the Global North from economic, gender and social interaction perspectives (Leridon 2015; Jalovaara et al. 2019). They all acknowledge the fact that with available and effective birth control techniques fertility has entered the realm of conscious choice and that lower fertility can have perceived advantages in the prevailing economic and social environment. These four theories are summarized in Table 1. 
Table 1. Theories and measures to explain fertility decline

\begin{tabular}{|l|l|l|l|}
\hline & $\begin{array}{l}\text { Central } \\
\text { hypothesis }\end{array}$ & $\begin{array}{l}\text { Drivers of } \\
\text { fertility decline }\end{array}$ & $\begin{array}{l}\text { Measurement } \\
\text { in previous } \\
\text { literature }\end{array}$ \\
\hline $\begin{array}{l}\text { 1. Micro- } \\
\text { economic } \\
\text { theory }\end{array}$ & $\begin{array}{l}\text { Fertility defined } \\
\text { in terms of } \\
\text { income effect } \\
\text { vs. price effect }\end{array}$ & $\begin{array}{l}\text { Drop in aggregate } \\
\text { incomes or increase } \\
\text { in unemployment } \\
\text { (income effect) }\end{array}$ & $\begin{array}{l}\text { Unemployment } \\
\text { among young } \\
\text { adults }\end{array}$ \\
\hline $\begin{array}{l}\text { 2. Gender theory: } \\
\text { gender equality }\end{array}$ & $\begin{array}{l}\text { Increase in opportunity } \\
\text { costs as a result of } \\
\text { to combine work } \\
\text { and family } \\
\text { (price effect) }\end{array}$ & $\begin{array}{l}\text { Double burden of paid } \\
\text { work and family } \\
\text { obligations }\end{array}$ & $\begin{array}{l}\text { Utilization of } \\
\text { parental benefits }\end{array}$ \\
\hline $\begin{array}{l}\text { 3. Gender theory: } \\
\text { gender equity }\end{array}$ & $\begin{array}{l}\text { Perception of } \\
\text { fairness in parental } \\
\text { roles }\end{array}$ & $\begin{array}{l}\text { Unfair division } \\
\text { of labor between } \\
\text { spouses }\end{array}$ & $\begin{array}{l}\text { Gender attitudes } \\
\text { towards } \\
\text { parenthood }\end{array}$ \\
\hline $\begin{array}{l}\text { 4. Social } \\
\text { interaction } \\
\text { theory }\end{array}$ & $\begin{array}{l}\text { Learning through } \\
\text { social networks } \\
\text { family life, positive } \\
\text { experiences/perceptions } \\
\text { of childless lifestyle }\end{array}$ & $\begin{array}{l}\text { Negative experiences/ } \\
\text { perceptions of }\end{array}$ & Surveys \\
\hline
\end{tabular}

Sources: Leridon 2015.

As data sources to assess the relevance and validity of the theories, we use previous literature on the Finnish context (Comolli 2019; Hellstrand et al. 2019; Berg 2018a, 2018b; Mäki 2019; Jalovaara et al. 2019; Tanskanen 2018; Hiilamo 2017; Rotkirch et al. 2017), as well as the following online statistical databases:

- Nordic statistics (https://www.nordicstatistics.org/population/),

- statistical database Kelasto on families from the Social Insurance Institution of Finland (https://www.kela.fi/web/en/statistical-database-kelasto_contents\#Families),

- statistical database PxWeb from Statistics Finland (https://pxnet2.stat.fi/PXWeb/pxweb/en/StatFin/) and

- Sotkanet statistical database on welfare and health in Finland (https://sotkanet.fi/sotkanet/en/index?). 


\section{Micro-economic theory}

In micro-economic theory, fertility is a function of socioeconomic resources available for, and the opportunity cost of, childbearing. This theory emerged with the invention of homo economicus, the rational actor whose behaviours can be predicted given the available choices. The central idea is that the changes in consumption of durable goods can be projected given the price and quality (or perceived satisfaction) of these goods and the elasticity of consumption against changes in income (Leridon 2015). The supply of children is assumed to be much greater than demand, so it need not to be quantified.

In his seminal Treatise on Family, Becker (1993) suggests that higher levels of socioeconomic resources positively influence couples' childbearing, also known as income effect. However, the income effect is also gendered; men's resources typically have a positive effect, while the opportunity cost effect is more relevant for women. The micro-economic theory considers both the direct costs of children and the lost earnings as a result of time spent taking care of the children. The theory predicts a fertility decline when incomes drop (income effect) or when opportunity costs of childbearing increase (price effect). The crucial issue is the extent to which income or price effect dominate in fertility decisions in a given context. Apart from direct income effects also perceived economic development may affect fertility (Comolli et al. 2019). Uncertain employment prospects may increase family instability or cast doubt on couple's ability to provide for children. For the same reasons improved economic outlooks should increase fertility.

Previous studies have investigated the income effect on fertility by taking advantage of aggregated unemployment and fertility rates (e.g., Goldstein et al. 2013; Comolli 2017; Hiilamo 2017). When the income effect dominates, rising unemployment should lead to lower fertility. If the price effect dominates, fertility may even increase since poorer employment prospects reduce the opportunity costs of having children (Table $1)$.

\section{Micro-economic theory in the Finnish context}

Finland experienced a deep but fairly short economic crisis in the early 1990s (Kalela et al. 2001). As the micro-economy theory predicts, the short economic recession did not reduce fertility despite the fact that economic resources diminished. This was because the higher unemployment accompanying the recession reduced the opportunity cost of childbearing, especially for women. This kind of counter-cyclical birth rate was observed for Finnish women in their 30s (Comolli 2018). However, the birth rates of women in their 20s were pro-cyclical in the 1990s.

For all age groups of women, the strong upswing in the economy in the late 1990s and in the beginning of the new millennium was associated with increasing fertility. Favourable economic conditions prevailed until the Great Recession in 2008. Since 
then, the economy stagnated until 2016 when the first signs of robust economic growth were finally visible. Interestingly, older women's counter-cyclical first birth rates did not reoccur during the Great Recession. What is even more unexpected from the microeconomic perspective is that pro-cyclical birth rates have not been experienced since the start of the more favourably economic conditions (Statistic Finland 2019a).

Earlier research has demonstrated the strong pro-cyclical effect of unemployment on fertility during the Global Recession between 2008 and 2015 (Hiilamo 2017). One individual-level study showed that female job loss decreased fertility (Huttunen and Kellokumpu 2016). Micro-economy theory fails to explain why women's pro-cyclical fertility pattern suddenly turned counter-cyclical in 2016/2017, when Finland finally emerged from recession. Since 2010, the fertility rate has decreased dramatically in all central age groups, except among women 35 to 39 years (Figure 2). Even in this group, fertility has declined since 2012. In the meantime, unemployment among men and women 25 to 34 years old, as well as men 35 to 44 years old, increased until 2015 and then started to decline (Figure 3) (Statistic Finland 2019c). For women 35 to 44 years old, unemployment started to decrease in 2017. However, the recession in the early 1990s in Finland was shorter but much more severe than the Global Recession (Comolli 2018; Hiilamo 2017). This means that the shifts in the labour market were not as visible between 2008 and 2019 as between 1991 and 1995. By mid-2019 there was no sign of an increase in fertility, on the contrary the decline continued (Statistic Finland 2019a).

Micro-economic theory suggests that to ensure the "quality of children", economic security and adequate housing are essential to having a child. Since 2016, a number of economic indicators besides employment have shown positive development in Finland (https://findikaattori.fi/en/). Housing prices have increased only modestly, in some areas the prices have actually dropped. Meanwhile mortgage rates have remained low. From the micro-economy theory perspective, this makes the decline in fertility ever more surprising. After reviewing fertility trends in Nordic countries in the 1990s and 2010s Comolli et al. (2019) conclude that economic theories do not suffice to explain a reversal from the heterogeneity of the 1990s to the homogeneity of the 2010s in the childbearing response to recession episodes across countries and socioeconomic groups. They call for expanding the theoretical framework to explain the cyclicality of fertility towards the perception of economic and welfare uncertainty. 
Figure 2. Age-specific fertility rates in Finland between 2006-2018.

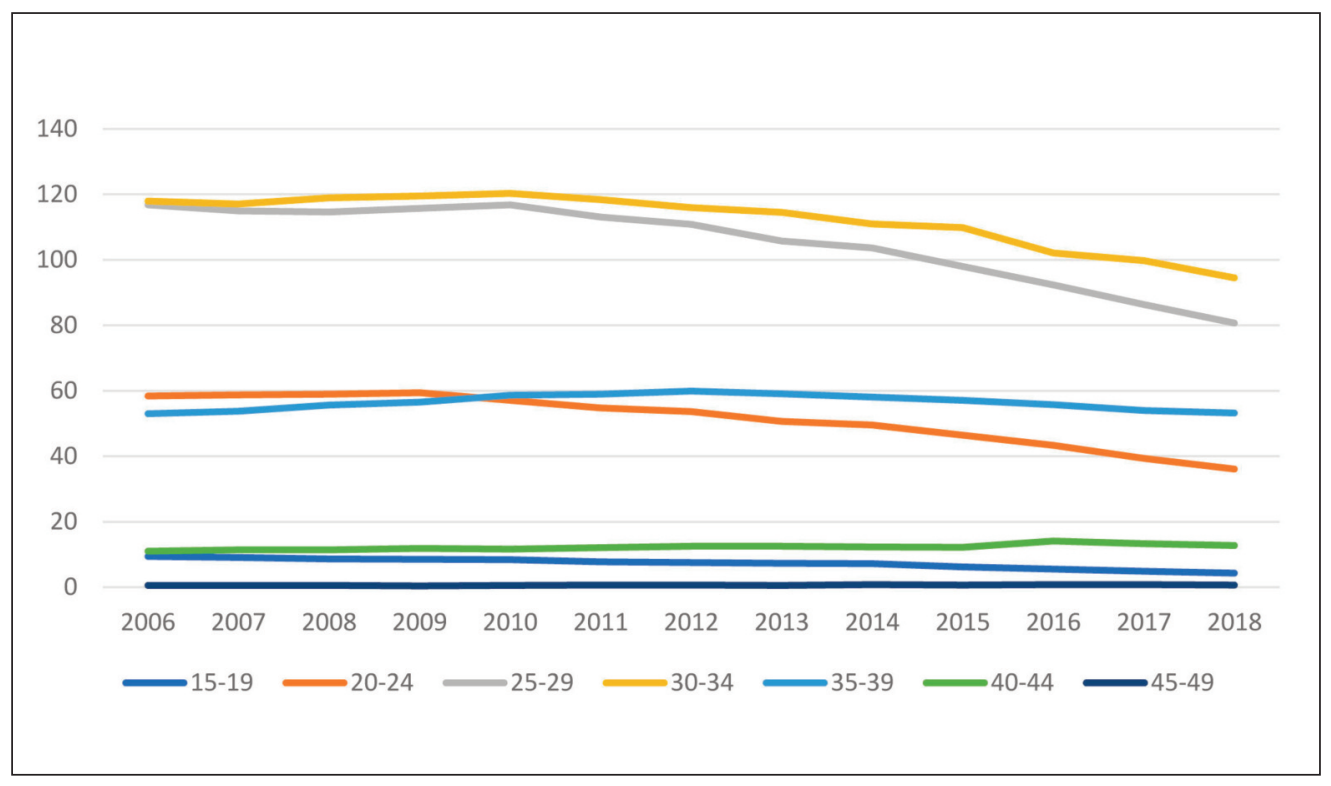

Source: Statistic Finland $2019 b$.

Figure 3. Unemployment by gender and age group, $\%$.

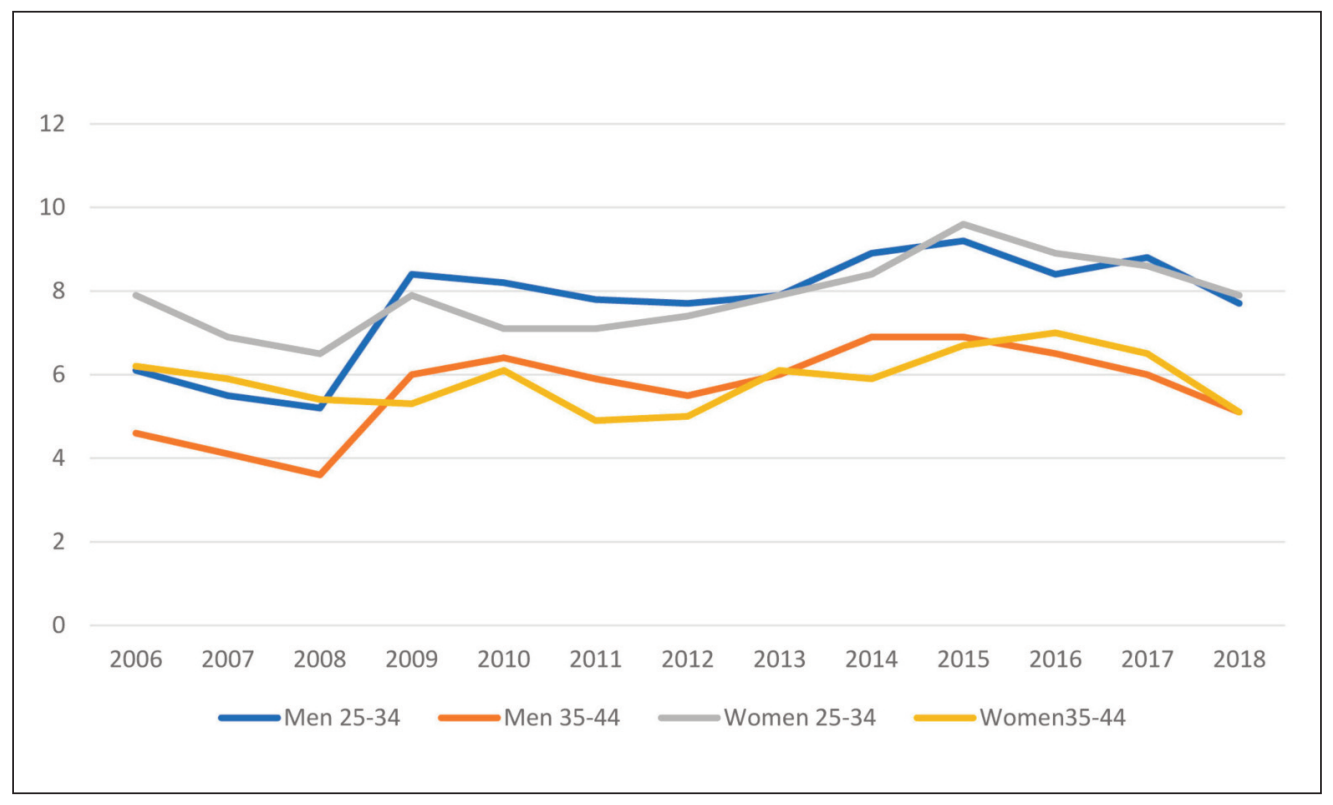

Source: Statistic Finland 2019c. 


\section{Gender theories: gender equality and equity}

The starting point of gender theories of fertility is that having children has different implications for mothers and fathers (Frejka et al. 2018). The crucial issue is women's opportunities to combine paid work and childbearing. The theories suggest that a decline in fertility is connected with women's rising participation in education and employment (Esping-Andersen and Billari 2015). In the absence of policies to balance work and family, women are faced with a double burden of paid work and unpaid care work. If women are faced with competing forces of a work career or a family life, they tend to choose either work or having children. The tough choice will decrease aggregate fertility since especially women with higher education and good career prospects choose to remain childless or have a smaller number of children.

Gender equality theory is closely linked to an institutional approach which suggests that welfare state institutions influence gender, social, or economic relationships in society as well as in the family. Their relationships are reflected in fertility patterns (Neyer 2003). The effect of women's opportunity cost of raising children can be mitigated through policies which support reconciling paid work and family life and through policies which encourage men to take more caring responsibilities and share family work more equally with their partners. According to gender equality theory, countries with greater gender equity should have higher fertility rates than more unequal countries. The effects of gender equality theory on fertility may be evaluated through public policies that support work and family reconciliation.

McDonald (2015) has developed the gender theory a step further by making a distinction between gender equality and gender equity. Unlike gender equality, gender equity allows for different outcomes for men and women, but requires the outcomes to be fair. McDonald asserts that the level of incongruence between gender equity in the family sphere and gender equity in education and the labour market is decisive for fertility. Couples negotiate fertility in the context of their relative care roles as mothers and fathers. What they consider fair will vary from couple to couple. The negotiation is also influenced by socio-economic circumstances.

Gender equity does not necessarily concern equality of outcome, but perceptions of fairness and opportunity. Improvements in women's education and labour market position vis-à-vis men has reduced women's constraints to fulfil their aspirations as individuals. This encourages them to weigh up their aspirations for achievement against their own and their partner's family aspirations. McDonald (2015) argues that some level of compromise is inevitable, but if the level of compromise is too severe some women will choose not to form a permanent relationship or to have no children or fewer children than they had intended. In gender equity theory, public institutions that support work and family balance are not decisive as such. What matters is how they are perceived by women in their social contexts. Attitude surveys may be used to measure these perceptions (Table 1). 


\section{Gender theories in the Finnish context}

The increase in the average age of first-time mothers offers an easy bio-cultural explanation for the declining trend in fertility. Given the biological limitations in female fertility, the completed fertility rate is bound to fall together with an increase in the average age of first-time mothers as more and more women do not have the number of children they wished for. However, the comprehensive statistics on assisted fertility treatments started between 2008 and 2017 do not show an increasing trend (Sotkanet 2019a). The figure has fluctuated between 13,451 (in 2017) and 14,463 (in 2011).

Earlier research has shown that at later phases of the demographic transition, countries with higher degrees of gender equality have been able to prevent fertility from falling to very low levels (Myrskylä et al. 2009). Before the Global Recession, the Nordic countries were recognised as countries with relatively high fertility rates due to a high degree of gender equality. Due to policies to reduce work-family conflicts, women were not forced to choose between having children or a work career (Björnberg and Ottosen 2013). Studies have shown that the theory works not only on an aggregate level but also on an individual level (Hellstrand et al. 2019).

The financial support for families with small children in Finland consists of two parts, parental benefits and a cash-for-case scheme called the Child Home Care Allowance (CHCA) for parents of children below the age of three, with a supplement for any older under-school-age child. In addition, there is a subjective right for a place in public day care ${ }^{1}$. Between 2008 and 2018 there were no major changes in the family policy institutions supporting work-family balance. A closer look into family policy shows that a number of piecemeal reforms were introduced between 2008 and 2014 to strengthen work-life balance, to increase gender equality and to improve the economic position of families (Nyby et al. 2018). Between 2015 and 2018 Finland implemented reductive policy adjustments, such as cuts to child benefits and the parental leave allowance. Finland continues to have affordable and high-quality childcare and extensive parental leave policies and supports the gender-equal division of care. Also, benefit utilisation statistics (Kelasto 2019) between 2007 and 2018 show a continuous increase in fathers' utilisation of benefits, although there is still a huge gap between fathers and mothers, especially in the number of reimbursed parental benefits days and in the utilization of CHCA (Figure 5).

1. In 2015 the municipalities were given the opportunity to limit the use of public daycare up to 20 hours if the parents are unemployed. However, not all municipalities utilised the opportunity. 
Figure 4. Fathers share among family policy benefits recipients, 2007-2018.

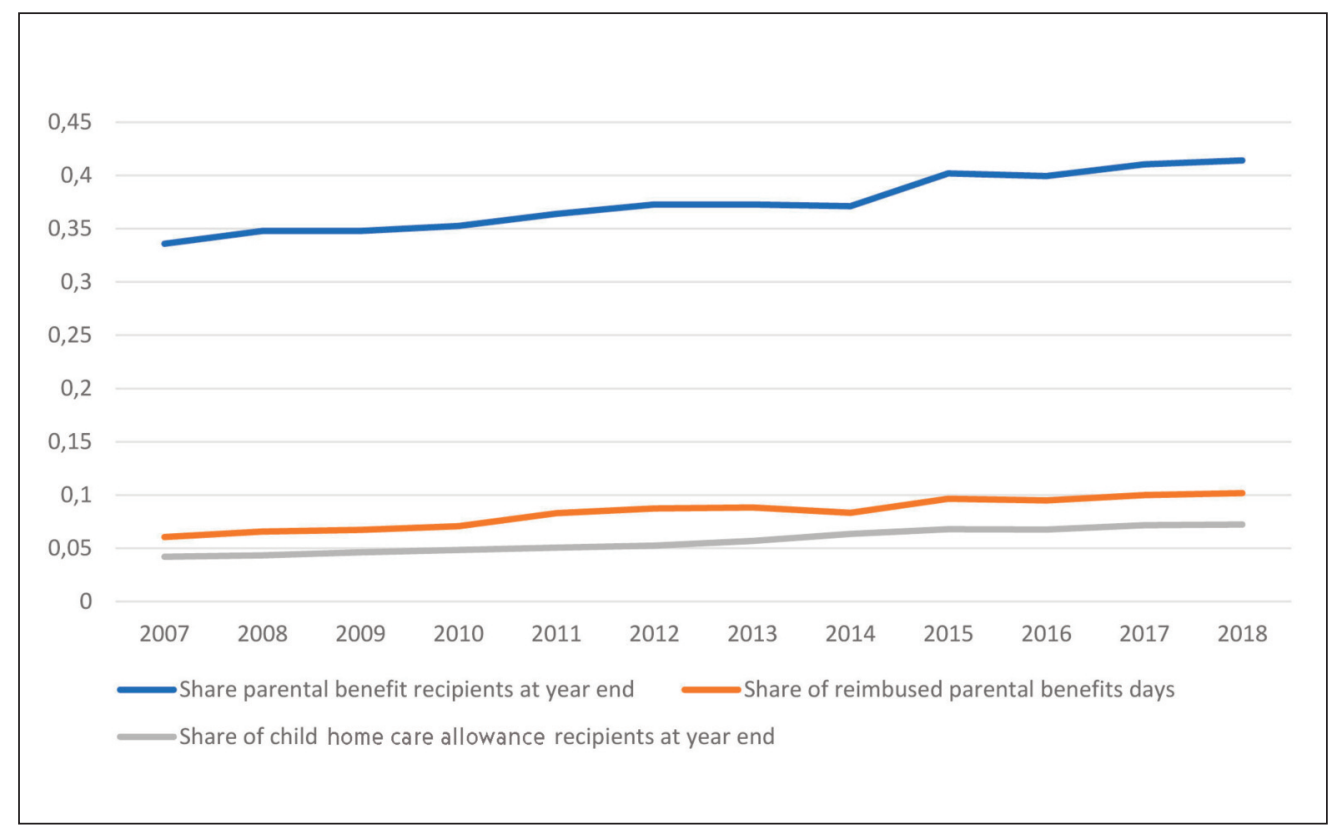

Source: Kelasto 2019.

Finland has also experienced a rapid educational expansion as well as reversal of the gender gap in education. After the Global Recession, the gender gap in education has become even more favourable to women. Women are increasingly inclined to partner with men who are less educated than themselves (Mäenpää and Jalovaara 2015) and who also in many cases earn more than their spouses. This might have created a need for even more progressive policies to work-family reconciliation and men's intensified participation in unpaid work at home. Fathers' participation in the care of small children has increased only very slowly (Figure 4) and two consecutive governments between 2011 and 2019 failed to deliver on a promised reform on benefits for the support of families with small children. The hypothesis is that the changes in the policies to support a work-family balance and changes in benefits utilization have not matched the changes in women's expectations. However, previous studies have failed to find empirical support for the hypothesis (Miettinen et al. 2011; Miettinen et al. 2015).

It is also worth considering the effect of the CHCA. The scheme allegedly contributed to counter-cyclical fertility during the 1990s recession (Comolli 2018). It is possible that the CHCA maintains the expectations of full-time mothers, which are increasingly in conflict with the career expectations of highly educated women. Jalovaara et al. (2019) showed that, indeed, Finland is an exception among the Nordic countries, 
with highly educated Finnish women having slightly fewer children than their less educated counterparts.

All in all, the changes in family policy benefits or in benefits utilization does not seem to explain the continuous fertility decline in Finland.

A recent register study from Iceland, Norway and Sweden showed a positive association between fathers' leave use and second births in all three countries (Duvander et al. 2019). However, there was a negative association between fathers' parental leave use and third births in Norway and Sweden. The results seem to indicate that more equal couples tend to prefer two child families, while families with a more traditional division of paid and unpaid work desire larger families. Taking this finding one step further would suggest that in some cases more gender equality would actually come with lower fertility. It is possible that when fathers take more responsibility for childcare they prefer to have fewer children than in the case of a more traditional division of tasks between genders. The finding calls for modification of existing gender theories by also examining the effects of parenthood for men.

Shifting the focus from gender equality to equity, we may posit that perceived conflict between work and family has been compounded in Finland. This is despite the stability in family policy benefits as well as an increase in the father's share as users of these benefits. Despite economic downturns, women's labour force participation, apart from single mothers, has increased, and their economic position has strengthened in society as well as in families (Jalovaara et al. 2019).

We may review opinion surveys to study if they show a compounded conflict between women's expectations of fairness in sharing parental burden in Finland. The Gender Equality Barometer has surveyed on opinions, attitudes and experiences related to gender equality in various areas of life since 1998. The sixth barometer, published in 2018, determined that there is a positive development in attitudes concerning equality in the labour market as well as well as in reduced support for men's role as breadwinners from 1998 to 2017 among both men and women (STM 2018). The survey also included questions concerning disagreements between spouses on different areas of family life. There is no upward trend between 2008 and 2017 among women who report "a lot" or "considerable amount" of disagreements with regard to the sharing of household chores, taking care of children or absence from work during child's illness (Figure 5). However, in 2017 as many as 40 percent of partnered women with under-school-aged children reported being at least occasionally unfairly overburdened with household work, while the corresponding figure for other women was 30 percent. For men, the figure was around 10 percent, both among those with and without under-school-aged children. Unfortunately, this question was not available in previous surveys. The Gender Equality Barometer is based on aggregate responses and does not specifically address attitudes concerning fertility. To study changes in women's attitudes, a more detailed and representative data on fertile-aged women's attitudes is needed. 
Figure 5. Share of women reporting considerable disagreement in three areas of family life, \%.

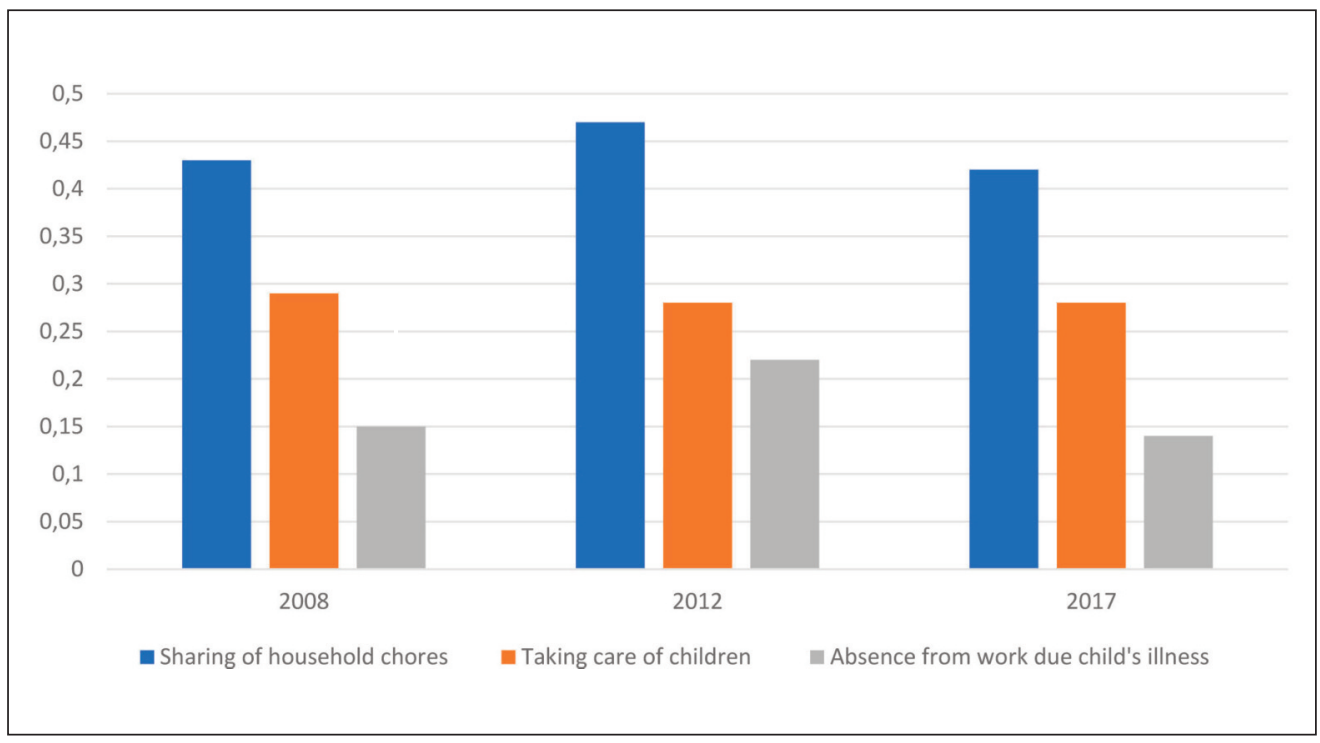

Source: STM 2018.

Since 1977, the Family Federation has surveyed parents' views on their desired number of children (Berg 2018a). A dramatic increase occurred in the share of those wanting no children and a decrease in the share of those wanting three or more children between 2007 and 2015. However, between 2015 and 2018, the attitudes turned more positive regarding having children. Contrary to gender equity theory, those with high incomes and high education were over-represented among those wanting large families and under-represented among those who desired no children. The survey in 2018 showed, for the first time, a gap in the desired number of children across different age groups of men and women, with those between 20 and 24 years showing lower expectations (Berg 2018b). Overall, it seems the survey results do not provide support to the gender equity hypothesis for the fertility decline in Finland.

\section{Social interaction theory}

The central notion in social interaction theory is that uncertainty associated with fertility is influenced by learning about the experiences of friends, neighbours, colleagues and other types of social networks (Bernardi and Klärner 2014). The theory assumes that individual beliefs and behaviours are interdependent and moderated by social interaction mechanisms and social structures. Social interaction comes with normative influences 
on preferences and attitudes which may concern a number of issues relating to fertility, including, for example, the timing of fertility, pregnancy and childbirth, and issues with parenthood. While micro-economic theory assumes that fertility decisions are based on the individual determination of costs and benefits, social interaction theory generally presumes that childbearing is a social act, and that individual beliefs and behaviours are interdependent and determined, to a certain degree, by social interactions and social structures. Previous literature has shown that social interactions matter a great deal for fertility (see Rossier and Bernardi 2009 for review). Family system norms and social networks have an influence on family size (Mönkediek and Bras 2016; Bühler and Fratczak, 2004). Friend's marriage and childbearing increases an individual's entry into marriage and risk of becoming a parent (Balbo and Barban 2014; Balbo et al. 2013).

A review of social networks and fertility by Bernardi and Klärner (2014) identifies four specific mechanisms of interaction, namely social learning, social pressure, social contagion, and social support (see also Rossier and Bernardi 2009). Social learning points to the process of the acquisition, exchange, and shared evaluation of information within a network through which individuals may adopt the behavioural models of others, reject these models, or learn about the consequences of different modes of actions. Social pressure deals with the force that leads individuals to conform to accepted social norms, for example in gender roles or household power structures, in order to gain the approval of their peers or to avoid conflict. Social contagion happens when a person catches an idea or behaviour from another person as a result of a social (mimicking) or emotional response, which is below the level of individual awareness. Social support operates as an exchange of goods (money) and services (e.g., childcare and household help) between related individuals.

Social interaction theory aligns with the notion of path dependence in the social processes linked to fertility decisions (Huinink et al. 2015). The patterns of childbearing affect future fertility by influencing individual attitudes in men's and women's lives, and may result in feedback loops which reinforce increasing or declining trends. An important aspect of social contagion and social learning concerns the experience of raising one's first child. Fertility intentions and expectations are modified by the personal experience of parenting, in particular after the life-changing experience of having the first child (Mencarini 2019). How this experience is communicated through social interaction matters for fertility decisions.

Lutz et al. (2005) suggest that feedback loops may create a "low fertility trap" where declining family size and increasing childlessness will lead to corresponding changes in cultural values and norms related to having children (see also Rotkirch et al. 2017). If a very small family becomes the norm among a majority of the population, future generations will have no alternative model to follow. That may be especially relevant in a context where population ageing gives more power to the oldest fraction of the population, the least concerned by policies to encourage childbearing (Lutz et al., 2005). Through social interaction this may result in even higher rates of childlessness and to even smaller family sizes. 
Threshold models suggest that cultural or economic factors affect fertility only if their strength exceeds a certain level. A decline in fertility may result from societal transformation and demographic transition processes, where a critical mass of couples decide to stay childless (Bernandi and Klärner 2014). The idea of childlessness (or having only one child) may gain ground due to contagion effects. If there are fewer and fewer children present in the social networks of adults, the wish to have children because others have children will be less likely to arise. Similarly, young adults' fertility behaviour may be influenced by their observations of childless people experiencing positive and joyful events as a result of their spontaneous and unencumbered lifestyle. In short, social interaction theory explains fertility decline through negative experiences or perceptions of family life as well as through positive experiences or perceptions of childless lifestyles. Modes of social interaction are complex and difficult to capture through research. One possibility is to collect and analyse data on social media use (Table 1).

\section{Social interaction theory in the Finnish context}

It is difficult to assess the extent to which changes in social interaction explain the fertility decline in Finland. We may assume that if a social network is very dense and homogeneous, social pressure may play an important role. That is clearly visible, for example, among the members of the Christian revival movement, the Laestadians. This group is known for its natural fertility, emphasising family values and guidelines including pre-marital abstinence and refraining from the use of contraception (Terämä, 2010). The Laestadians continue to have a clearly higher than average fertility in Finland. It is possible, however, that continuous urbanisation has reduced the social pressure to have children while at the same time has exhausted opportunities for social support through, for example, grandparenting.

If the social network is sparse and heterogeneous, social contagion and social learning may have a larger impact. The dramatic increase in the use of the internet and social media may have changed the speed of behavioural changes through social interactions which relate to social contagion and social learning. Tanskanen's (2018) empirical analysis suggests that increases in the use of social media (share of active social media users) explain a major part of the decline in fertility between 2012 and 2017. Although not establishing causality, the result is interesting as the first attempt to study the role of social media in fertility decisions. It is clear that fertility-related issues are frequently discussed on the internet and social media in Finland. That is demonstrated, for example, by the fact that one of the most popular internet platforms is an online discussion forum on babies, "vauva.fi" (FIAM 2019).

To further illustrate this point, we compare monthly Google Trends search volume indexes with the Finnish word for pregnancy ("raskaus") and volume indexes for children born in each month between January 2007 and June 2019. Google Trends 
(https://rends.google.com/trends) shows how frequently a given search term is entered into Google's search engine relative to the site's total search volume over a given period of time. There is a declining trend for both indexes (Figure 6). The correlation coefficient for the two indexes with 0 to 12 month lags scored between 0.516 and 0.635 , with the highest values for both 7 and 12 month lags. The results show that the internet is an important source for fertility related social interaction.

Figure 6. Trend in Google search for word "raskaus" (pregnancy) and number of children born per month, year 2007=100.

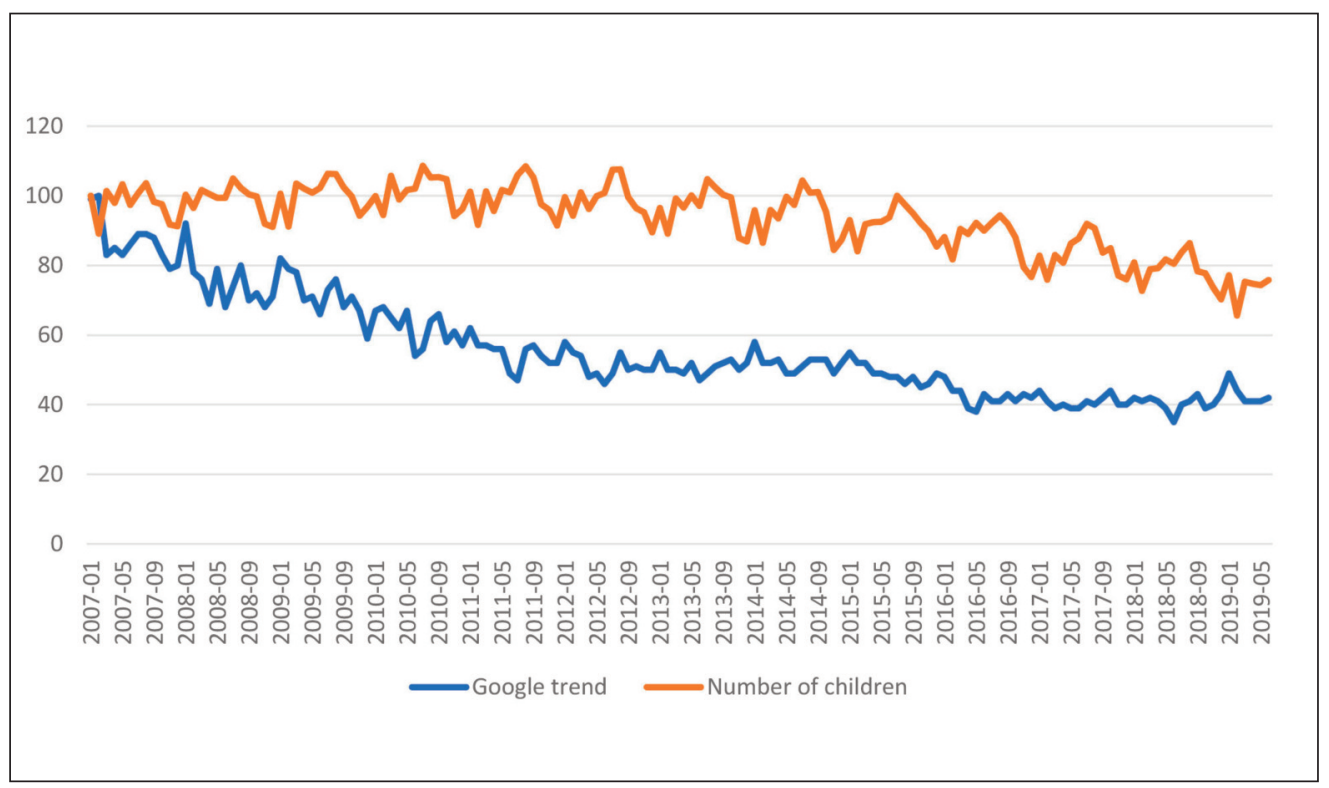

Source: Google Trends 2019.

There is also a need to look into the role of social media on special social groups. For example, the delivery rates in the subregion of Nivala-Haapajärvi and Oulu, two of the strongholds of the Lestadian revival movement, have declined from 2007 to 2017, even faster than in the whole country (Figure 7) (delivery rates are used because Sotkanet does not report TFR's). Social media has opened a new forum for Lestadian women to discuss issues previously considered taboos, including the ban on contraceptives (Hintsala 2017). Watkins and Danzi (1995) showed in their anthropological study how fertility declines among Italian and Jewish women in the United States during the period between 1920 and 1940 were initiated and accelerated through women's social interactions relating to birth control techniques. 
Figure 7. Delivery rate per 1000 women aged 15-49 years in two sub-regions and the whole country.

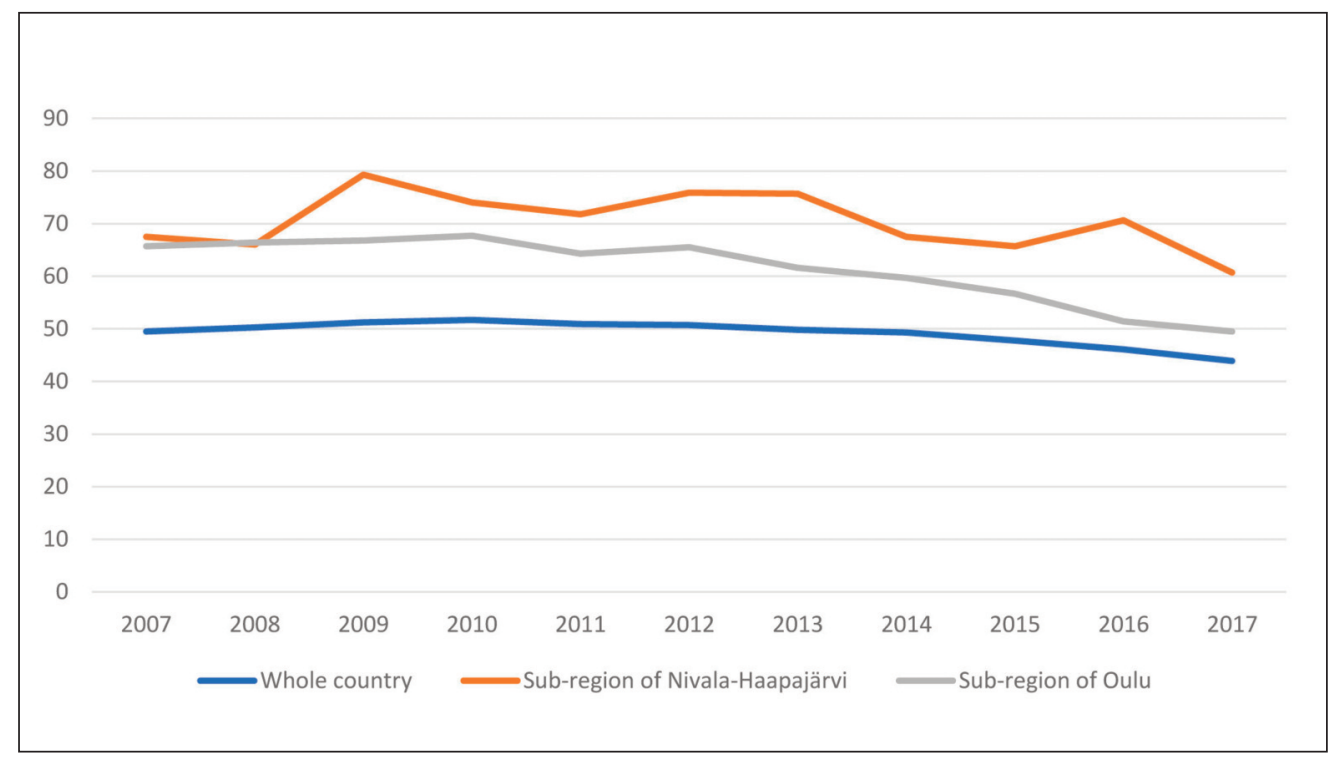

Source: Sotkanet 2019 c.

What is interesting in the Finnish context is that social learning and social contagion are not related to the opportunity cost logic of action (Montgomery and Casterline 1996; Kohler 2001). The opportunity costs of having children were reduced during the Global Recession, but then increased as a result of the improved employment situation since 2016.

Basten (2010) relates the recent diffusion of childlessness to the role of social media, especially to a growing number of groups that defend and promote childfree lifestyles on Facebook and other social media sites (see also Rotkirch et al. 2017: 83-84). Indeed, in Finland there is a lively group for the Association of Voluntary Childless People ("Vapaaehtoisesti lapsettomat ry, https://www.facebook.com/vapaaehtoisestilapsettomat/). There is also an active Association for People Who Live Alone in Finland (Yksinasuvat ry). Both associations work to normalise childless lifestyles and to promote the interests of childless people. The normalisation of childless lifestyles may undermine the cultural idea that becoming a parent would be an important life goal and a marker of personal success, thereby leading to social recognition and feelings of pride and satisfaction (Mencarini 2019).

Finally, the fear of environmental degradation in general and climate change in particular have also been mentioned as reasons for low fertility in Finland. The claim is that young people will not bring new children into a world which is already over-populated and on the verge of ecological collapse. This line of thinking actually resembles 
Thomas Malthus' (1766-1834) argument calling for moral restraint instead of allowing death to curb population growth (Leridon 2015). Ignoring the possibility of productivity growth, Malthus argued that food production would only increase at an arithmetic rate while the population tended to grow at a geometric rate, therefore, he exhorted couples to voluntarily limit their family size so that the population would not grow beyond the capacity of food production. It is possible that environmental concerns are weighed in fertility considerations in Finland. However, to our knowledge there is no time-series data to analyse the matter.

The current literature offers few clear clues on how to evaluate the pervasiveness of the internet and social media and its effect on fertility decisions. We may only speculate whether problem-oriented discussion on childbearing and parenthood through social learning and/or social contagion has discouraged fertility. However, increases in the use of social media is not unique to Finland, although climate conditions in Northern Europe may emphasise its role in social interactions. Another avenue for exploration would be to study if the ostensibly limitless availability of partners through online dating sites has made finding a stable partnership more difficult - or if the use of pictures or more generally visualization of dating has had a similar effect. The marriage rate has decreased considerably in Finland during the last decade, which may indicate more problems in finding suitable partners (Statistic Finland 2019). In 2008 there were nearly 33,000 opposite-sex marriages, while in 2018 the corresponding figure was only 23,400 marriages.

\section{Discussion}

This paper sought to examine the extent to which three old and two more recent fertility theories explain the somewhat puzzling fertility decline in Finland after the Global Recession in 2008. The main conclusion is that changes in economic conditions (microeconomic theory) or public policies to reconcile the work- family conflict (gender equality theory) do not seem to explain the fertility decline in Finland from 2010 to 2018. The same goes for changes in women's attitudes towards family life or gender equity more generally (gender equity theory). Cost-benefit rationales also underpinning these standard approaches to the study of fertility do not seem to elucidate the continuing decline in fertility (see also Ellingsæter and Pedersen 2016). Instead, it seems plausible that changes in the structure of social interaction, more specifically in social contagion and social learning may better explain fertility development. However, it is challenging to find data sources which could describe the role of social interaction in fertility decline. Overall, of course, the validity of theories cannot be evaluated by looking at aggregate developments in one country during a short period of time.

Explaining changes in the TFR is challenging since there are most likely multiple causes for the same outcome, some increasing and some decreasing the TFR. Since individuals are affected by changes in their environment, it is necessary to consider sep- 
arate effects in four areas. As the great majority of children are born to couples, we need to consider changes in couple formation (1) and couple stability (2) as factors explaining changes in the TFR. For couples, it is necessary to distinguish those considering having their first child (3) and those considering higher parities (4). Having a child can be perceived as a life-changing experience disrupting the conjugal relationship, which cannot be compared with the decision of having another child. While the TFR reflects aggregate effects of development in all four areas, it is important to note the temporal order of different factors: couple formation is a precondition for fertility, while couple dissolution is an exclusive factor.

Micro-economic theory is mainly preoccupied with a couple's fertility decisions, while ignoring the role of couple formation and dissolution in fertility. Empirical work has tried to fill in the gap (e.g. Jalovaara and Kulu 2018). A pitfall in gender theories is that the level of gender equality or equity in a society does not directly affect the fertility of those who do not find a partner (Jalovaara and Fasang 2017). The strength of social interaction theory is that it captures all four areas identified above. People form their partnership expectations as well as their expectations towards having children through social learning. Social contagion affects norms and attitudes concerning all four areas. As indicated above, the problem with social interaction theory is that it is challenging to draw testable hypotheses from the theory. We may only speculate if unrealistic expectations towards future partners have been created through social media and if social media is also used to communicate more negative impressions of childbearing and more positive impressions of childless lifestyles. In any case, a comprehensive analysis of fertility decline should focus not only on childbearing but also on partnership formation and partnership stability. Future analysis could utilize surveys to study social interaction effects on different aspects of fertility behaviours, for example use of contraception, fertility ideals and intentions, parity-specific norms, age norms, parenting norms, partnership patterns etc.

Some words of caution concerning the validity of micro-economic and gender theories are warranted though. An additional analysis on regional-level data might be fruitful to see, for example, if changes in local employment and housing markets have influenced fertility (Lainiala and Berg 2017). As to gender theories, there is an urgent need to expand the theory towards the male perspective (e.g., Jalovaara et al. 2019). Despite the still existing gender inequalities in labour market outcomes, the trend towards the equalisation of care work at home may have unexpected fertility consequences (e.g., Duvander et al. 2019).

The reversed gender gap in education is also an area which needs further analysis, as it may hinder partnership formation and thereby reduce fertility (Van Bavel 2012). Indeed, among the 70 sub-regions in Finland only 3 sub-regions with universities (Helsinki, Rovaniemi and Turku) had more women than men in the age group of 20 to 29 years in 2018 (the most skewed male-to-female ratio of 1.53 was observed in the Eastern Finland sub-region of Kehys-Kainuu) (Sotkanet 2019b, Appendix Table 1A). Since 1990, the male-to-female ratio has become more skewed (Sotkanet 2019b). Sub- 
regional variation in the male-to-female ratio is most likely caused by female educational migration to university cities (Lainiala and Miettinen 2014). Girls systematically outperform boys throughout the educational system in Finland. More detailed regional analyses by educational and income groups are needed to further explore the sex-ratio hypothesis.

Analysis of fertility mechanisms is also difficult due to the possibility of time lags from effect to response. Social, cultural, economic, demographic or political changes may all follow different time scales, and the interdependencies between them are not yet well understood. It is, for example, possible that the declining trend in fertility in Finland actually started long before the Global Recession, but its effects were overshadowed by the counter-cyclical timing of childbearing (Comolli 2018).

These findings are challenging for politicians who might want to design pro-natalistic policies, since the findings indicate that neither successful economic policy nor more progressive family policies may immediately change the declining trend in fertility. That does not mean that the fertility rate is beyond the control of public policies. The way in which politicians as opinion leaders speak about children and perhaps also about the future will surely also have an effect on more private social interactions relating to fertility decisions.

As Greenhalgh $(1990,85)$ notes, 'it seems that the closer we get to understanding specific fertility decline, the further we move from a general theory of fertility transition'. This paper has demonstrated that there are clear limitations of the current mainstream fertility theories to explain Finnish fertility in the post-2008 period. This highlights the need for more research from the Finnish context. Previous research on fertility has a strong foundation in register studies. With register data, it is fairly easy to study hypotheses derived from micro-economic theory and gender equality theory. The registers include information on incomes as well as on the use of family policy benefits. While also rich in socio-economic backgrounds, register data lack essential information to explain couples' attitudes and motivations. The collection of high-quality survey data is necessary for further analysis. Social interaction analysis methods also provide a promising avenue for the exploration of fertility decisions. For that purpose, there is an urgent need to collect and utilise social media data.

\section{Data sources}

Findicator (2019). Economy. Information on social phenomena in the form of a statistical graph, table and analyzing text. https://findikaattori.fi/en

Google Trends (2019). (https://trends.google.com/trends

Kelasto (2019). Statistics on families from Social Insurance Institution of Finland (https://www.kela.fi/web/en/statistical-database-kelasto_contents\#Families (Accessed July 30, 2019)

Nordic Statistics (2019). CHIL02: Fertility rates by reporting country, age and time. Nordic Statistics Database. https://www.nordicstatistics.org/population/ (Accessed August 3, 2019) 
Sotkanet (2019a). Started assisted fertility treatments (all treatments, total) (ind. 2307).

(Accessed July 30, 2019)

Sotkanet (2019b). Population aged 20-24 and 25-29, year-end total (ind. 989).

(Accessed July 30, 2019)

Sotkanet (2019c). Delivery rate per 1000 women aged 15-49 (ind. 677). (Accessed July 30, 2019)

Statistic Finland (2019a). Vital statistics by month.

http://pxnet2.stat.fi/PXWeb/pxweb/en/StatFin/StatFin_vrm_vamuu/statfin_vamuu_pxt_111l.px/ (Accessed July 30, 2019)

Statistic Finland (2019b) Age-specific fertility rates by Year, Information and Age of mother http://pxnet2.stat.fi/PXWeb/pxweb/en/StatFin/StatFin_vrm_synt/statfin_synt_pxt_009.px/ (Accessed August 7, 2019)

Statistic Finland (2019c). Population by labor force status, sex and age, monthly data, 1989M012019M06.

https://pxnet2.stat.fi/PXWeb/pxweb/en/StatFin/StatFin_tym_tyti_kk/statfin_tyti_pxt_11af.px (Accessed July 30, 2019)

STM (2018)): Tasa-arvobarometri 2017: Sosiaali- ja terveysministeriön julkaisuja 8/2018

\section{References}

Balbo, N., \& Barban, N. (2014). Does Fertility Behavior Spread among Friends? American Sociological Review, 79(3), 412-431. https://doi.org/10.1177/0003122414531596

Balbo, N, Barban, N \& Mills, M. (2013). Friend and peer effects on entry into marriage and parenthood: A multiprocess approach. Working Papers 056, "Carlo F. Dondena” Centre for Research on Social Dynamics (DONDENA), Università Commerciale Luigi Bocconi.

Basten, S. (2010) Television and Fertility Finnish Yearbook of Population 45, 67-82

Bastian, M. \& Bras, H. (2016) The Interplay of Family Systems, Social Networks and Fertility in Europe Cohorts Born Between 1920 and 1960. Economic History of Developing Regions 31(1): 136-166. https://doi.org/10.1080/20780389.2015.1109441

Becker, G. (1993). A Treatise on the Family. Enlarged edition. Cambridge, MA: First Harvard University Press.

Berg ,V. (2018a). Lapsilukuihanteet, lapsiaikeet ja syyt lastensaannin lykkäämiseen Suomessa 2018. Esitelmä Väestöliiton seminaarissa 16.5.2018. http://vaestoliitto-fibin.directo.fi/@Bin/0f4c48d21e34427c712633d715d8226a/1564484263/application/pdf/83801 33/VenlaBerg_lapsilukuihanteet_160518_julk.pdf (Accessed July 30, 2019)

Berg, V. (2018b). Suomalaiset haluavat nykyään vähemmän lapsia kuin ennen. https://www.vaestoliitto.fi/tieto_ja_tutkimus/vaestontutkimuslaitos/tietovuodot/touko-2018-tietovuoto/ (Accessed July 30, 2019)

Bernardi, L., \& Klärner, A. (2014). Social networks and fertility. Demographic research 30(22), 641-670. https://doi.org/10.4054/DemRes.2014.30.22

Björnberg, U., \& Ottosen, M. (eds.) (2013). Challenges for future family policies in the Nordic countries. Copenhagen: SFI - the Danish National Centre for Social Research.

Bongaarts, J., \& Feeney, G. (1998). On the Quantum and Tempo of Fertility. Population and Development Review 24(2), 271-291. https://doi.org/10.2307/2807974

Bühler, C. \& Fratczak, E. (2004). Social capital and fertility intentions: the case of Poland. MPIDR Working Papers WP-2004-012. Rostock: Max Planck Institute for Demographic Research. https://doi.org/10.4054/MPIDR-WP-2004-012 
Comolli, C. (2017) The fertility response to the Great Recession in Europe and the United States: Structural economic conditions and perceived economic uncertainty. Demographic research 36(51), 1549-1600. https://doi.org/10.4054/DemRes.2017.36.51

Comolli, C. (2018). Finnish fertility: Pro- or counter-cyclical? Research on Finnish Society 11, 58-64.

Comolli, CL., Neyer, G., Andersson, G., Dommermuth, L., Fallesen, P., Jalovaara, M., Jónsson, A., Kolk M \& Lappegard, T. (2019). Beyond the Economic Gaze Childbearing during and after recessions in the Nordic countries. Stockholm: Stockholm Research Reports in Demography 2019:16

Duvander, A-Z., Lappegård, T., Andersen, S., Garðarsdóttir, Ó., Neyer, G. \& Viklund, I. (2019) Parental leave policies and continued childbearing in Iceland, Norway, and Sweden. Demographic Research 40(51): 1501-1528. https://doi.org/10.4054/DemRes.2019.40.51

Ellingsæter, A-L. \& Pedersen, E. (2016). Institutional Trust: Family Policy and Fertility in Norway. Social Politics 23(1): 119-141. https://doi.org/10.1093/sp/jxv003

Esping-Andersen, G. \& Billari, FC. (2015). Re-theorizing family demographics. Population and Development Review 41(1): 1-31. https://doi.org/10.1111/j.1728-4457.2015.00024.x

FIAM (2019): Finnish Internet Audience Measurement. https://fiam.fi/tulokset/ (Accessed July 30, 2019)

Frejka, T., Goldscheider, F. \& Lappegård, T. (2018). The Two-Part Gender Revolution, Women's Second Shift and Changing Cohort Fertility. Comparative Population Studies. 43: 99-130

Goldstein, J., Kreyenfeld, M., Jasilioniene, A. \& Örsal, D. K. (2013). Fertility reactions to the 'Great Recession' in Europe: Recent evidence from order-specific data. Demographic Research 29(4), 85-104. https://doi.org/10.4054/DemRes.2013.29.4

Greenhalgh, S. (1990). Toward a Political Economy of Fertility: Anthropological Contributions. Population and Development Review, 16(1), 85-106. https://doi.org/10.2307/1972530

Hellstrand, J., Nisén, J. \& Myrskylä M. (2019). All-time low period fertility in Finland: drivers, tempo effects, and cohort implications. MPIDR Working Paper. WP 2019-006. https://doi.org/10.4054/MPIDR-WP-2019-006

Hiilamo, H. (2017). Fertility Response to Economic Recessions in Finland 1991-2015. Finnish Yearbook of Population Research 52(1): 15-28. https://doi.org/10.23979/fypr.65254

Hintsala, M-A. (2017). Elämää uskonrukouksessa - Eletty usko vanhoillislestadiolaisten ehkäisykeskusteluissa verkossa. Teologinen Aikakauskirja 122 (3), 226-240.

Huinink, J., Kohli, M. \& Ehrhardt, J. (2015). Explaining fertility: The potential for integrative approaches. Demographic Research 33(4). 93-112. https://doi.org/10.4054/DemRes.2015.33.4

Huttunen, K., \& Kellokumpu, J. (2016). The Effect of Job Displacement on Couples' Fertility Decisions. Journal of Labor Economics 34 (2), 403-442. https://doi.org/10.1086/683645

Jalovaara, M. \& Kulu, H. (2018). Separation risk over union duration: An immediate itch? European Sociological Review 34(5), 486-500. https://doi.org/10.1093/esr/jcy017

Jalovaara, M., G. Neyer, G. Andersson, J. Dahlberg, L. Dommermuth, P. Fallesen \& Lappegård, T.. (2018). Education, Gender, and Cohort Fertility in the Nordic Countries. European Journal of Population, 34, 1-24. https://doi.org/10.1007/s10680-018-9492-2. https://doi.org/10.1007/s10680-018-9492-2

Jalovaara, M. \& Fasang A. (2017). From never partnered to serial cohabitors: union trajectories to childlessness. Demographic Research 36(55), 1703-1720. https://doi.org/10.4054/DemRes.2017.36.55

Kalela, J,. Kiander, J., Kivikuru, U., Loikkanen, H., \& Simpura, J. (eds.) (2001). Down from the Heavens, Up from the Ashes. The Finnish Economic Crisis of the 1990s in the Light of Economic and Social Research. VATT Publications 27:6. Helsinki: Government Institute for Economic Research. 
Kohler, H-P., Billari, F. \& Ortega, JA. (2001). Towards a Theory of Lowest-Low Fertility. MPIDR Working Paper, No. WP 2001-032. https://doi.org/10.4054/MPIDR-WP-2001-032

Lainiala, L., \& Berg, V. (2016). Spatial trends of fertility rates in Finland between 1980 and 2014. Finnish Yearbook of Population Research 51, 89-95. https://doi.org/10.23979/fypr.63337

Lainiala, L., \& Miettinen, A. (2014). Skewed Marriage Markets and Sex Ratios of Finnish People in their Twenties. Finnish Yearbook of Population Research, 48, 51-63

Leridon, H. (2015): The Development of Fertility Theories: A Multidisciplinary Endeavour. Population-E, 70 (2), 2015, 309-348 https://doi.org/10.3917/popu.1502.0331

Lutz, W., Skirbekk V., \& Testa, MR. (2005). The low fertility trap hypothesis: Forces that may lead to further postponement and fewer births in Europe. Vienna: Vienna Institute of Demography.

McDonald, P. (2015). Societal foundations for explaining low fertility: Gender equity. Demographic Research 28(34). 981-994 https://doi.org/10.4054/DemRes.2013.28.34

Mencarini, L. (2019): Is It All About Happiness? The latest evidence on wellbeing and childbearing decisions in Europe. Population \& Policy Compact Policy Brief 22. July 2019. https://www.population-europe.eu/policy-brief/it-all-about-happiness (Accessed August 3, 2019)

Miettinen, A., Basten, S., Rotkirch A (2011). Gender equality and fertility intentions revisited: Evidence from Finland. Demographic research 24(20), 469-496.

https://doi.org/10.4054/DemRes.2011.24.20

Miettinen, A., Lainiala, L., \& Rotkirch, A. (2015). Women's housework decreases fertility: Evidence from a longitudinal study among Finnish couples. Acta Sociologica, 58(2), 139-154 https://doi.org/10.1177/0001699315572028

Montgomery, M. and Casterline, J. (1996) Social Learning, Social Influence and new Models of Fertility. Populations and Development Review 22 (1), 151-75

Myrskylä, M., Kohler, H. P. \& Billari. F. C. (2009). Advances in development reverse fertility declines. Nature, 460, 741-3. https://doi.org/10.1038/nature08230

Mäki, N (2019). Hedelmällisyys Helsingissä ennätysalhaisella tasolla - nuorten ikäryhmien hedelmällisyys pienentynyt voimakkaasti. Kvartti 26.06.2019. https://www.kvartti.fi/fi/artikkelit/hedelmallisyys-helsingissa-ennatysalhaisella-tasolla-nuorten-ikaryhmien-hedelmallisyys?fbclid=IwAR3gN2BSxRd9zf6WQ_1Ej8ou6PLxiL3Y_r8maBy0-mfMqHpogOlIMURNLxE

Mäenpää, E., \& Jalovaara, M. (2015). Achievement replacing ascription? Changes in homogamy in education and social class origins in Finland. Advances in Life Course Research, 26, 763-788. https://doi.org/10.1016/j.alcr.2015.09.001

Neyer, G. (2003). Family policies and low fertility in Western Europe. Journal of Population and Social Security (Population), 1(Supplement), 43-93. https://doi.org/10.4054/MPIDR-WP-2003-021

Nyby, J. , Nygård, M. \& Blum, S. (2018), Radical Reform Or Piecemeal Adjustments? The Case of Finnish Family Policy Reforms. European Policy Analysis, 4 (2), 190-213. https://doi.org/10.1002/epa2.1045

Rotkirch, A., Tammisalo, K., Miettinen, A., Berg, V. (2017). Miksi vanhemmuutta lykätään? Nuorten aikuisten nảkemyksiä lastensaannista. Perhebarometri. Väestöliitto, Helsinki.

Tanskanen, AJ. (2018): Sosiaalisen median aktiivikäyttö ja syntyvyys. https://ajtanskanen.github.io/syntyvyys_some.html (Accessed July 30, 2019)

Terämä, E. (2010). Regional Demographic Differences: the Effect of Laestadians. Finnish Yearbook of Population Research 45, 123-141.

Van Bavel, J. (2012). The reversal of gender inequality in education, union formation and fertility in Europe. Vienna Yearbook of Population Research, 10: 127-54. https://doi.org/10.1553/populationyearbook2012s 127

Watkins, S. C., \& Danzi, A. D. (1995). Women's gossip and social change: Childbirth and Fertility Control among Italian and Jewish Women in the United States, 1920-1940. Gender \& Society, 9(4), 469-490. https://doi.org/10.1177/089124395009004005 